\title{
DINAMIKA INTERAKSI AGEN DAN STRUKTUR DALAM MENCEGAH KONSENTRASI KEPEMILIKAN MEDIA TELEVISI
}

\author{
Nursatyo \\ Prodi llmu Komunikasi \\ Universitas Nasional, Jakarta \\ Email :nursatyo3@gmail.com
}

\begin{abstract}
The acquisition PT IDKM by PT EMTEK that have an impact of the unification INDOSIAR and SCTV in the same holding company between period 2011 - 2012, bring a nation-wide discussion about concentration of media television ownership in Indonesia. Broadcast act no.32/2002 with Indonesia Broadcasting Commision as an independent regulatory body considered weak in the face of concentration. This paper provide a comprehensive description about the dynamics interaction between agent and structure of Indonesian broadcasting system particularly in order to organize commercial television media ownership.
\end{abstract}

Keywords: media ownership concentration, Indonesian broadcasting structure

\section{Pendahuluan}

Proses demokratisasi di Indonesia yang terjadi pasca reformasi membawa pengaruh pada ranah penyiaran. Dunia penyiaran yang mengatur media radio dan televisi dihadapkan pada paradigma baru yang muncul dalam Undang-Undang no.32 tahun 2002 tentang Penyiaran. Yang dimaksud dengan paradigma baru tersebut adalah paradigma "ruang publik" yang menempatkan publik sebagai pemilik dan pengendali utama ranah penyiaran. $\mathrm{Hal}$ ini berlawanan dengan paradigma "pasar", yang memandang bisnis penyiaran harus didudukkan sama dengan dunia bisnis pada umumnya, dengan semakin minimnya campur tangan pemerintah akan menciptakan efisiensi ekonomi.

Paradigma pasar berasumsi, masyarakat akan terlayani dengan cara yang optimal bila segenap pertimbangan bisnis diserahkan kepada dinamika penawaran dan permintaan (hukum pasar). Melalui kompetisi yang fair diantara para pelaku pasar, maka, akan membuat produsen memberikan produk yang terbaik bagi konsumen dengan harga murah (Armando, 2011). Jika dikaitkan dengan bisnis penyiaran khususnya televisi, maka, paradigma pasar akan dipahami; bahwa semakin diberikan kebebasan seluas-luasnya bagi lembaga penyiaran televisi untuk mengatur dirinya sendiri melalui mekanisme pasar, maka, akan dapat menciptakan program siaran yang bagus sesuai dengan keinginan pasar (masyarakat).

Sebaliknya, paradigma "ruang publik" menganggap, bisnis penyiaran berbeda dengan bisnis pada umumnya. Armando mengemukakan tiga argumentasi mengapa dunia penyiaran harus diatur ketat (high regulated) untuk kepentingan publik (Armando, 2011). Pertama, media penyiaran televisi diyakini memiliki kekuasaan yang besar untuk mempengaruhi audiens. Apalagi media penyiaran televisi memiliki sifat pervasiveness yang mampu masuk ke ranah domestik tanpa diundang.

Kedua, media penyiaran televisi juga berperan sebagai ruang diskusi publik (public sphere) yang menuntut media sebagai wadah menampung informasi dan opini masyarakat yang beragam tanpa khawatir dan takut terhadap kekuasaan, baik kekuasaan politik maupun ekonomi. Ketiga, dan yang terpenting, frekuensi yang digunakan oleh media penyiaran televisi sifatnya terbatas dan merupakan milik 
publik seperti halnya kekayaan alam air, tanah dan udara.

Ketiga argumentasi itulah yang kemudian digunakan dalam paradigma ruang publik untuk mengatur dunia penyiaran. Kekuasaan media yang besar, keharusan media untuk menjadi ruang diskusi publik dan terbatasnya frekuensi, menyebabkan penataan media penyiaran membutuhkan intervensi pihak non-media. Ketergantungan media yang sangat besar dari iklan dapat menjadikan media lebih berpihak dan melayani pengiklan yang di belakangnya adalah para pemodal besar. Dalam hal ini, bisa saja, media tidak responsif terhadap kebutuhan publik.

UU Penyiaran menegaskan bahwa seluruh praktik penyiaran di Indonesia harus didasarkan demi kepentingan publik. Pasal 6 ayat 2 UU 32/2002 menyatakan "Dalam sistem penyiaran nasional sebagaimana dimaksud dalam ayat (1), Negara menguasai spektrum frekuensi radio yang digunakan untuk penyelenggaraan penyiaran guna sebesar-besarnya kemakmuran rakyat.". Pemanfaatan untuk kepentingan publik, artinya; publik berhak menerima isi siaran yang sehat dan lembaga penyiaran harus menjalankan fungsi pelayanan informasi publik yang sehat.

Munculnya paradigma Ruang Publik dalam UU Penyiaran itulah yang kemudian melahirkan sebuah lembaga negara independen untuk mengatur dunia penyiaran (Independent Regulatory Body), yang kemudian diberi nama Komisi Penyiaran Indonesia (KPI).

Dalam penyiaran, KPI yang lahir dengan membawa paradigma ruang publik, diharapkan mampu menjadi representasi publik dalam menghadapi kekuatan pemodal (kekuasaan ekonomi) dan pemerintah (kekuasaan politik). Dalam UU Penyiaran disebutkan, KPI merupakan lembaga negara yang bersifat independen sebagai wujud peran serta masyarakat di bidang penyiaran. KPI berasal dari unsur masyarakat madani yang berupaya untuk menciptakan keseimbangan di antara kekuatan negara dan pasar dalam industri penyiaran.

Sebagai lembaga pengawal kepentingan masyarakat, maka, KPI memiliki tugas menegakkan prinsip diversity of content (keberagaman isi) dan diversity of ownership (keberagaman kepemilikan), dengan tetap berusaha memperbaiki diri untuk kepentingan bersama.

Keduaprinsiptersebutmenjadilandasan bagi setiap kebijakan yang dirumuskan oleh KPI. Pelayanan informasi yang sehat berdasarkan prinsip keberagaman isi adalah tersedianya informasi yang beragam bagi publik, baik berdasarkan jenis program maupun isi program. Sementara, prinsip keberagaman kepemilikan adalah jaminan bahwa kepemilikan media massa yang ada di Indonesia tidak terpusat dan dimonopoli oleh segelintir orang atau lembaga saja.

Prinsip Diversity of Ownership juga menjamin iklim persaingan yang sehat antara pengelola media massa dalam dunia penyiaran di Indonesia. Pasal 18 ayat 1 UU 32/2002 menyebutkan "Pemusatan kepemilikan dan penguasaan Lembaga Penyiaran Swasta oleh satu orang atau satu badan hukum, baik di satu wilayah siaran maupun di beberapa wilayah siaran, dibatasi."

Namun, akhir Februari 2011, dunia penyiaran diramaikan dengan rencana penggabungan usaha antara PT Indosiar Karya Media Tbk (IDKM) yang merupakan perusahaan pemilik lembaga penyiaran INDOSIAR dengan PT Elang Mahkota Teknologi Tbk (EMTEK) perusahaan induk dari PT Surya Citra Media Tbk (SCM) yang menaungi lembaga penyiaran SCTV. Rencana penggabungan usaha tersebut diungkapkan oleh Handoko, Direktur Utama IDKM dalam keterbukaan informasi Bursa Efek Indonesia (BEI), di Jakarta, Senin (21/2/2011) (www. okezone.com, Indosiar dan SCTV Merger! 21 Februari 2011, 15:01 wib, diunduh melalui http://economy.okezone.com/ read/2011/02/21/278/427049/indosiarsctv-merger). 
Aksi korporasi yang dilakukan EMTEK adalah dengan membeli seluruh saham PT Prima Visualindo (PV) pemilik saham mayoritas di PT Indosiar Karya Media Tbk (IDKM) yang merupakan pemilik saham tunggal di PT Indosiar Visual Mandiri (IVM) yang menaungi stasiun televisi Indosiar. Sementara, EMTEK merupakan perusahaan induk dari PT Surya Citra Media Tbk (SCM) yang menaungi lembaga penyiaran SCTV. Artinya aksi korporasi EMTEK tersebut berakibat pada bergabungnya SCTV dengan Indosiar dalam sebuah perusahaan induk yang sama.

Sejak itu, perdebatan penggabungan SCTV dan INDOSIAR mengemuka di berbagai media massa. Banyak kalangan yang menilai usaha merger tersebut berimplikasi pada konsentrasi/ pemusatan kepemilikan media. Seketika, hal ini mendapat kecaman dari kalangan pengamat penyiaran -- termasuk KPI -yang menganggap usaha merger tersebut menyalahi UU Penyiaran.

Setelah melakukan beberapa kali pertemuan dengan EMTEK dan IDKM serta pihak pemerintah; Kementerian Komunikasi dan Informatika (Kemenkominfo) dan Badan Pengawas Pasar Modal dan Lembaga Keuangan (Bapepam LK), maka, pada 7 Juni 2011, KPI Pusat mengeluarkan pandangan hukum (legal opinion) atas kasus tersebut.

KPI menyatakan; rencana aksi korporasi PT EMTEK sebagai pemilik $86 \%$ saham PT SCM yang memegang $99,9 \%$ saham PT SCTV, dan mengambil alih keseluruhan saham milik PT PV di PT IDKM, pemegang 99,9\% saham PT IVM, berpotensi melanggar Pasal 18 ayat (1) dan Pasal 34 ayat (4) UU 32/2002 tentang Penyiaran, serta Pasal 32 ayat (1) huruf(a) Peraturan Pemerintah No.50 Tahun 2005 tentang Lembaga Penyiaran Swasta (PP-LPS) (Dokumen Pandangan Hukum KPI).

KPI berpendapat, PT SCTV dan PT IVM adalah lembaga penyiaran swasta yang sama-sama berlokasi di provinsi DKI Jakarta. Dengan demikian, pengambilalihan tersebut mengakibatkan PT EMTEK sebagai
1 (satu) badan hukum memiliki 2 (dua) izin penyelenggaraan penyiaran (IPP) jasa penyiaran televisi yang berlokasi di 1 (satu) provinsi. Sudah barang tentu, hal ini menyalahi Pasal 32 ayat (1) huruf (a) PP-LPS yang berbunyi

"Pemusatan kepemilikan dan penguasaan Lembaga Penyiaran Swasta pada penyiaran televisi oleh 1 (satu) orang atau 1 (satu) badan hukum, baik di satu wilayah siaran maupun di beberapa wilayah siaran, di seluruh Indonesia dibatasi sebagai berikut: 1 (satu) badan hukum paling banyak memiliki 2 (dua) izin penyelenggaraan penyiaran jasa penyiaran televisi, yang beralokasi di 2 (dua) provinsi yang berbeda."

Selain itu, KPI melandaskan argumentasi yuridis pada Pasal 34 ayat (4) UU Penyiaran yang berbunyi :

"Izin penyelenggaraan penyiaran dilarang dipindahtangankan kepada pihak lain" dengan penjelasan "yang dimaksud dengan izin penyelenggaraan penyiaran dipindahtangankan kepada pihak lain, misalnya izin penyelenggaraan penyiaran yang diberikan kepada badan hukum tertentu, dijual, atau dialihkan kepada badan hukum lain atau perseroan lain."

IPP yang diberikan kepada PT IVM, yang semula 99,9\% sahamnya dikuasai PT IDKM, sebagai anak perusahaan PT PV, karena keseluruhan PT PV diambil alih PT EMTEK, dianggap telah dipindahtangankan ke PT EMTEK sebagai badan hukum yang telah memiliki IPP.

Akhirnya, kasus akuisisi ini berkembang menjadi isu tentang kepemilikan media penyiaran televisi swasta di Indonesia melalui langkah yang diambil oleh Koalisi Independen untuk Demokratisasi Penyiaran (KIDP) dengan mengajukan uji materi (Judicial Review/JR) pasal 18 ayat (1) dan pasal 34 ayat (4) UU Penyiaran ke Mahkamah Konstitusi (MK).

Dalam perkembangannya, melalui Putusan Nomor: 78/PUU-IX/2011 tertanggal 
3 Oktober 2012, MK menolak permohonan KIDP tentang tafsir konstitusional atas pemusatan kepemilikan televisi dan jualbeli izin penyelenggaraan penyiaran (IPP). Menurut MK, dalam pertimbangan hukumnya tidak terdapat multitafsir terhadap pasal 18 ayat (1) dan pasal 34 ayat (4) UU Penyiaran. Dan akhirnya aksi korporasi akuisisi IDKM oleh EMTEK berhasil dilakukan.

Dalam teori strukturasi Giddens, tindakan manusia merupakan suatu proses produksi dan reproduksi berbagai sistem sosial. Sebuah tindakan individu didasarkan pada aturan-aturan untuk mencapai tujuan mereka, dan dengan itu menciptakan struktur yang pada gilirannya mempengaruhi tindakan-tindakan di masa mendatang. Struktur memberikan individu aturan-aturan yang menuntun tindakan mereka, akan tetapi, pada gilirannya, tindakan individu tersebut menciptakan aturan baru dan mereproduksi aturanaturan lama (LittleJohn, 2002).

Giddens menyatakan terdapat interaksi antara agen dan struktur yang bersifat dualitas, seperti dua sisi koin yang berbeda tapi merupakan satu kesatuan. Struktur tidak akan pernah ada tanpa agen, dan agen tidak dapat berperan tanpa struktur. Tindakan agen berfungsi untuk memproduksi dan mereproduksi struktur sosial, dan struktur sosial secara simultan memungkinkan sekaligus menghambat tindakan agen.

Hal inilah yang menimbulkan ketertarikan penulis untuk mendalami dinamika interaksi antara agen dan struktur penyiaran di Indonesia dalam proses akuisisi IDKM oleh EMTEK. Metode penelitian dalam tulisan ini menggunakan paradigma kritis lewat pendekatan penelitian kualitatif deskriptif (Alan Bryman, 2008:366) dengan desain penelitian studi kasus (case study) dengan desain single case atau single unit of analysis (Robert K. Yin, 2003:13), selanjutnya, data dijadikan bahan analisis.

\section{Proses Akuisisi IDKM oleh EMTEK}

Sejatinya, rencana aksi korporasi
IDKM oleh EMTEK muncul jauh sebelum 2011. Menurut keterangan informan M. Riyanto, Ketua Komisioner KPI Pusat periode 2010-2013, rencana aksi korporasi EMTEK terhadap IDKM telah ia terima sekitar 2008/2009. Saat itu, EMTEK sudah melaporkan kepada KPI mengenai rencana aksi korporasi tersebut. Menurut Ketua KPI M. Riyanto:

"Sebenarnya, proses aksi korporasi ini sudah sejak 2008 atau 2009, rencana aksi ini sudah terjadi. Saya lupa tanggalnya ketika dulu mereka kesini untuk melaporkan dan menyampaikan rencana itu. Pihak SCTV, EMTEK, baru menyampaikan rencana. Waktu itu, kami terus merespons, mungkin, aksi korporasi bisa dilakukan dalam konteks "bisnis penyiaran", tapi kalau mengarah pada penguasaan izin siaran dan lain-lain, hal itu berpotensi pada pelanggaran terhadap UndangUndang. Itu advokasi yang kami berikan pada waktu pertemuan."

Bahkan, jauh lebih lama lagi, pada 2006 majalah Tempo telah melansir isu penjualan saham Indosiar kepada Trans TV dan SCTV. Dalam judul berita "Lebih Baik Tak Sendirian" Edisi. 39/XXXV/20-26 November 2006, Tempo mendapat kabar bahwa PT Indosiar Karya Media Tbk, akan melakukan rights issue alias menawarkan saham baru kepada para investor. Dana hasil penjualan saham itu akan dipakai melunasi utang obligasi Rp 696 miliar, yang jatuh tempo pada Agustus 2008. Saat itu, kondisi media penyiaran televisi hanya menyisakan tiga stasiun televisi yang belum bergabung dalam grup media; Indosiar, SCTV dan Metro TV. Menurut Mulya Chandra, analis Danareksa yang menjadi narasumber Tempo; SCTV dan Indosiar merupakan target akuisisi yang potensial (Lebih Baik Tak Sendirian, Majalah Tempo Edisi. 39/XXXV/20 - 26 November 2006).

Dalam beberapa pemberitaan di media massa, sejumlah pihak dari dalam maupun luar negeri juga pernah dikabarkan berencana untuk membeli Indosiar. Namanama konglomerat media seperti Erick 
Thohir pemilik PT Mahaka Media Tbk dan Chairul Tanjung pemilik grup media Trans Corp, kabarnya sangat berminat untuk membeli Indosiar. Begitu juga $A B C$ Development Corp yang menjalankan TV5 Filipina, juga diberitakan berencana untuk membeli Indosiar.

Rencana pelepasan saham IDKM tentu saja tidak dapat dilepaskan dari penurunan kinerja anak perusahaan IDKM yakni PT Indosiar Visual Mandiri (IVM) yang mengurus langsung kegiatan penyiaran stasiun televisi Indosiar. Sejak semester kedua 2004, peringkat Indosiar terus merosot. Fenomena itu terjadi ketika Indosiar memilih tidak ikut-ikutan menyajikan tayangan hantu-hantuan, yang ternyata diminati penonton di Indonesia. Persoalan lain, akibat keterbatasan menara transmisi, di seluruh wilayah Jakarta, tayangan Indosiar juga tidak prima. Bahkan, dilihat dari programnya, ketika itu, tayangan Indosiar masih mengandalkan program impor. Sudah barang tentu, hal itu membuat kinerja keuangannya terus merosot. Laba bersihnya sejak 2005 sudah minus. Hingga kuartal ketiga 2006, rugi bersihnya mencapai Rp 183,2 miliar. Dibanding 2005, pendapatan iklannya menurun sampai 29 persen (Majalah Tempo).

Selama 2005 hingga 2007, IDKM berturut-turut menderita rugi $\mathrm{Rp} 141,2$ miliar, Rp 297,6 miliar, dan Rp 129,3 miliar. Baru pada 2008 Indosiar mencatat laba bersih Rp 19,6 miliar. Selanjutnya, pada 2009 hingga 2010 IDKM mencatat penurunan laba bersih menjadi Rp 8,5 miliar dan Rp 8,3 miliar (http://investasi.kontan.co.id/news/ persaingan-ketat-indosiar-merugi-rp-20- $\underline{\text { miliar). }}$

Penurunan kinerja keuangan perusahaan, pada akhirnya berdampak pada persoalan tenaga kerja. Pada awal 2010, terjadi konflik antara manajemen dengan karyawan Indosiar; ketika sejumlah karyawan yang tergabung dalam Serikat Karyawan (Sekar) Indosiar menuntut kesejahteraan dan kenaikan gaji yang tidak diberikan selama enam tahun. Manajemen Indosiar justru menjawab tuntutan pekerja tersebut dengan memecat anggota dan seluruh pengurus Sekar Indosiar. Saat itu, Aliansi Jurnalis Independen (AJI) mencatat hampir 217 karyawan Indosiar dipecat (Laporan Tahunan Aliansi Jurnalis Independen (AJI) Tahun 2010, hlm. 9).

Sebagai sebuah badan hukum, Indosiar didirikan pada 19 Juli 1991 dengan nama perseroan PT Indovisual Citra Persada. Kemudian, pada 1995, Indosiar pertama kali bersiaran secara nasional. Hingga perubahan nama menjadi PT Indosiar Karya Media (IDKM) pada 2003, namun, perusahaan ini belum memiliki perusahaan induk (holding company). Barulah pada 4 Oktober 2004, IDKM menjadi perusahaan induk yang mendirikan anak perusahaan dengan nama PT Indosiar Visual Mandiri (IVM) yang mengurus kegiatan penyiaran stasiun televisi Indosiar. Kepemilikan saham IDKM di IVM sebesar 99,99\%. Sementara komposisi pemegang saham IDKM dimiliki oleh PTPrima Visualindo sebesar 27,24\% dan sisanya dimiliki pihak lain secara bersamasama (Laporan Tahunan PT Indosiar Karya Media Tbk Tahun 2010: 20-22). Keterkaitan IDKM dengan Indosiar dapat digambarkan sebagai berikut:

Gambar 1. Hubungan IDKM dengan LPS Indosiar

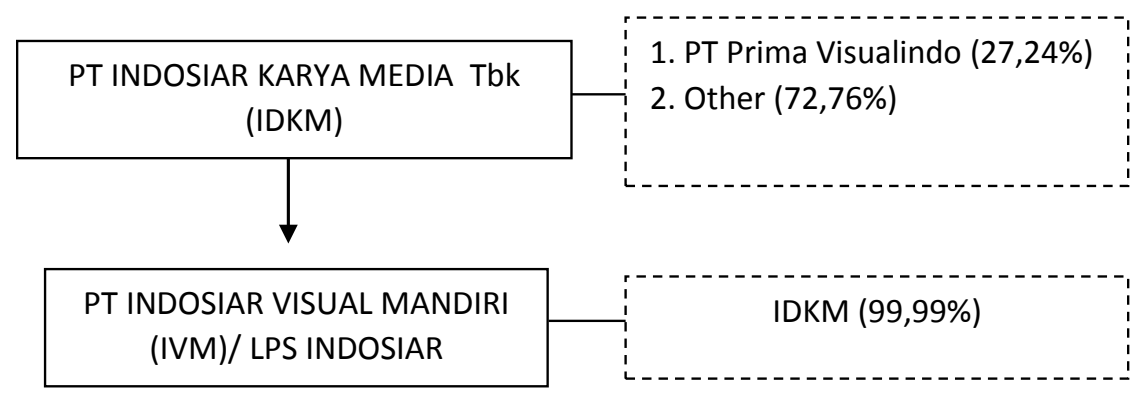

Sumber : diolah dari Laporan Tahunan PT Indosiar Karya Media Tbk Tahun 2010 
Pasca pengumuman rencana aksi korporasi oleh Direktur Utama IDKM, Komisi Penyiaran Indonesia (KPI) pada 24 Februari 2011 memanggil direksi Indosiar dan SCTV. Pertemuan yang berlangsung tertutup di kantor KPI Pusat ini dihadiri oleh Fofo Sariaatmadja, Direktur Utama SCTV dan Triandy Suyatman, Direktur Program Indosiar, digelar secara terpisah. Ternyata dari hasil pertemuan tersebut diketahui bahwa penggabungan usaha antara EMTEK dan IDKM baru sebatas wacana. Pada pertemuan itu, Ketua KPI Pusat, Dadang Rahmat Hidayat mengingatkan agar rencana aksi korporasi tersebut jangan sampai melanggar Undang-Undang Penyiaran dan Peraturan Pemerintah terkait (http://lifestyle.okezone.com/ $\mathrm{read} / 2011 / 02 / 24 / 278 / 428405 /$ ketua-kpimerger-indosiar-sctv-tak-boleh-langgarundang-undang).

Setelah didorong oleh Bursa Efek Indonesia dan Bapepam-LK untuk memperjelas bentuk aksi korporasi yang akan dilakukan, akhirnya, EMTEK melakukan aksi korporasi dengan cara mengambil alih 27,24\% saham IDKM milik PT Prima Visualindo pada 1 Maret 2011 melalui penandatanganan perjanjian jual beli bersyarat. Harga transaksi saham IDKM yang disepakati sebesar Rp 900 per saham, lebih murah dari harga pasar sebesar Rp 1.010 per saham. Biaya yang dikeluarkan EMTEK untuk membeli 551.708.684 saham tersebut sebesar $\operatorname{Rp} 496,54$ miliar (http://economy.okezone.com/ read/2011/03/03/278/430888/akhirnyasctv-akuisisi-indosiar-rp496-54-miliar). Pasca akuisisi saham Prima Visualindo, EMTEK juga mengeluarkan biaya lagi sebesar Rp 1,17 triliun untuk penawaran tender (tender offer) sisa saham IDKM di luar PV sebanyak 1.473.905.135 lembar saham, sehingga total saham IDKM yang diakuisisi oleh EMTEK berjumlah 84,77\%.

Pada awal berdirinya 1983, PT Elang Mahkota Teknologi Tbk (EMTEK), merupakan perusahaan yang bergerak di bidang jasa personal komputer. Hingga 2011, EMTEK memiliki tiga divisi bisnis utama; divisi media, divisi solusi dan divisi konektivitas. Pada divisi media, EMTEK memiliki 2 saluran televisi free to air yaitu SCTV dan O Channel. EMTEK juga mendirikan PT Screenplay Produksi, sebuah rumah produksi. Sementara, pada divisi solusi, EMTEK menyediakan serangkaian infrastruktur dan jasa informasi, layanan komunikasi dan solusi teknologi untuk industri telekomunikasi, perbankan dan pembayaran ritel, seperti jasa untuk VSAT terintegrasi dan Smart Card. Adapun divisi konektivitas terdiri dari dua inisiatif pengembangan untuk televisi dan layanan internet, termasuk layanan wireless digital pay TV dan layanan internet wireless broadband (Laporan Tahunan PT Elang Mahkota Teknologi Tbk Tahun 2010:3).

Komposisi pemegang saham di EMTEK adalah Eddy K. Sariaatmadja (20,8\%), Susanto Suwarto (13,8\%), Piet Yaury $(11,6 \%)$, Fofo Sariaatmadja (5,8\%) dan sisanya $48 \%$ dimiliki oleh publik baik perorangan maupun perusahaan. Kepemilikan EMTEK di SCTV merupakan kepemilikan langsung (direct ownership) melalui saham sebesar 85,78\% di PT Surya Citra Media Tbk (SCMA). SCMA inilah yang kemudian memiliki 99,99\% saham di PT Surya Citra Televisi (SCTV). Keterkaitan EMTEK dengan SCTV dapat digambarkan sebagai berikut: 
Gambar 2. Hubungan EMTEK dengan LPS SCTV

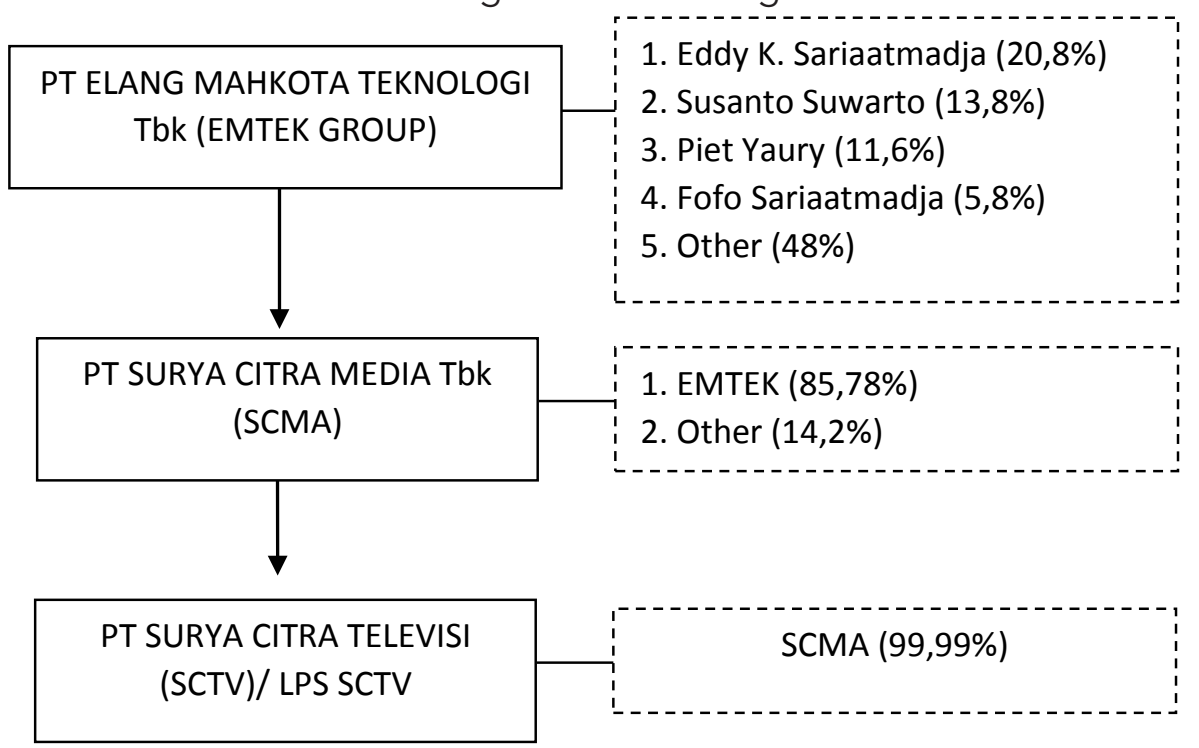

Sumber : diolah dari Laporan Tahunan PT Elang Mahkota Teknologi Tbk Tahun 2010

Pasca aksi korporasi akuisisi saham IDKM oleh EMTEK menyebabkan EMTEK memiliki saham mayoritas di dua perusahaan; yaitu di SCM sebesar $85,78 \%$ dan di IDKM sebesar $84,77 \%$ yang secara tidak langsung menguasai saham SCTV dan IVM. Hal ini dapat digambarkan dalam skema sebagai berikut:

\section{Gambar 3. Posisi EMTEK dengan LPS SCTV dan INDOSIAR}

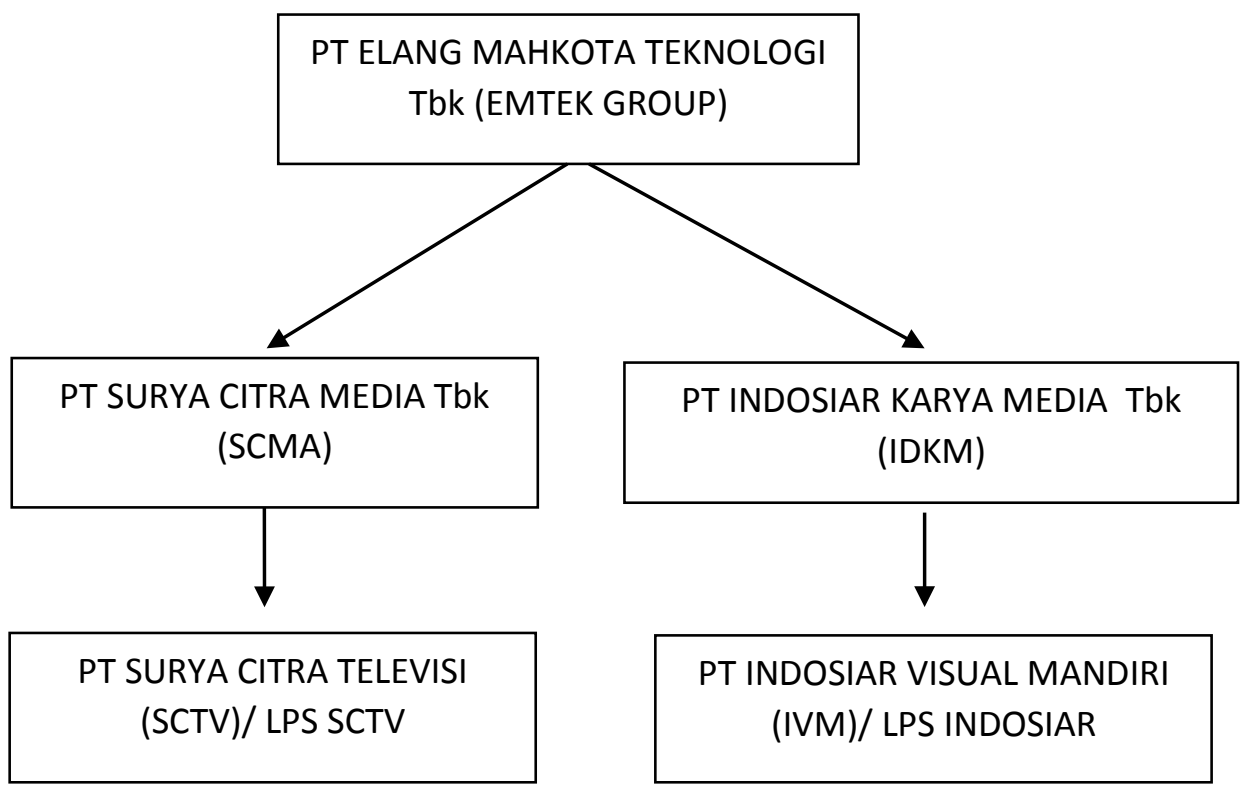

Sumber Daya Autoritatif \& Alokatif dalam Struktur Kepemilikan Media di Indonesia

Menurut Giddens sumber daya dalam sebuah struktur dapat dibagi ke dalam sumber daya autoritatif dan sumber daya alokatif (Giddens, 1984:100). Sumber daya autoritatif dalam kaitannya dengan struktur penyiaran di Indonesia adalah kekuasaan atau kewenangan yang dimiliki oleh Kemenkominfo, KPI dan industri televisi. Sedangkan sumber daya alokatif adalah ketersediaan kanal frekuensi dan pendapatan iklan.

Pengecualian terhadap 10 LPS Eksisting (unsur pengistimewaan terhadap 10 LPS yang sudah ada) dapat diartikan sebagai kekuasaan (power) industri televisi swasta nasional eksisting. Hal itu 
dapat dikategorikan sebagai sumber daya (resources) autoritatif dalam struktur kepemilikan media penyiaran di Indonesia. Struktur kepemilikan pada aspek sumber daya autoritatif juga menyangkut kekuasaan atau kewenangan yang dimiliki oleh lembaga-lembaga yang terkait dengan kebijakan di ranah penyiaran. UU Penyiaran melahirkan sebuah lembaga negara independen yang bertugas untuk mengatur dunia penyiaran (independent regulatory body). Lembaga tersebut bernama Komisi Penyiaran Indonesia (KPI).

KPI awalnya diharapkan mampu menjadi representasi publik dalam menghadapi kekuatan pemodal (kekuasaan ekonomi) dan pemerintah (kekuasaan politik). Dalam UU Penyiaran disebutkan bahwa Komisi Penyiaran Indonesia (KPI) merupakan lembaga negara yang bersifat independen sebagai wujud peran serta masyarakat di bidang penyiaran (UU Penyiaran). KPI berasal dari unsur masyarakat madani yang berupaya untuk menciptakan keseimbangan diantara kekuatan negara dan pasar dalam industri penyiaran.

Sebagai representasi publik, anggota KPI Pusat dipilih oleh Dewan Perwakilan Rakyat Republik Indonesia dan KPI Daerah dipilih oleh Dewan Perwakilan Rakyat Daerah Provinsi atas usul masyarakat melalui uji kepatutan dan kelayakan secara terbuka. Anggota KPI Pusat secara administratif ditetapkan oleh Presiden atas usul Dewan Perwakilan Rakyat Republik Indonesia dan anggota KPI Daerah secara administratif ditetapkan oleh Gubernur atas usul Dewan Perwakilan Rakyat Daerah Provinsi. Masa jabatan anggota KPI adalah 3 (tiga) tahun.

Pada awalnya, masyarakat penyiaran menaruh harapan yang besar terhadap KPI untuk dapat menata sistem penyiaran Indonesia. Namun harapan itu pupus, saat MK pada Juli 2004 mengeluarkan keputusan atas pengajuan uji materi (Judicial Review) terhadap UU Penyiaran yang dilakukan oleh 6 organisasi mitra industri; Asosiasi Televisi Swasta Indonesia (ATVSI), Ikatan Jurnalis Televisi Indonesia (IJTI), Persatuan Radio Siaran Swasta Nasional Indonesia (PRSSNI),
Persatuan Perusahaan Periklanan Indonesia (PPPI), Persatuan Sulih Suara Indonesia (Persusi) dan sebuah organisasi praktisi penyiaran Kom Teve.

Meskipun secara umum keputusan MK adalah menolak permintaan para pemohon JR untuk membatalkan UU Penyiaran, namun MK memutuskan bahwa KPI tak lagi memiliki wewenang untuk menjadi pihak yang bersama-sama pemerintah membuat peraturan pemerintah sebagai peraturan pelaksanaan UU Penyiaran. Ini terkait dengan rangkaian pasal UU yang menyatakan bahwa ketentuan lebih lanjut mengenai sejumlah hal harus ditetapkan oleh "KPI bersama-sama Pemerintah". Menurut MK, anak kalimat "KPI bersamasama" harus dihilangkan. Implikasinya yang berhak membuat rangkaian ketentuan lebih lanjut itu adalah hanya pemerintah (Armando, 2011:198-199).

Keputusan MK itulah yang mereduksi kewenangan KPI dalam mengatur kepemilikan media penyiaran di Indonesia. KPI diposisikan hanya berwenang dalam mengatur dan mengawasi isi siaran media. Sementara lembaga yang berwenang dalam pengaturan kepemilikan media penyiaran adalah Kemenkominfo. Dalam soal perizinan, KPI hanya berperan sebagai perantara antara pemohon dengan menteri. Keluarnya PP-LPS tahun 2005 semakin menguatkan peran dan wewenang Kemenkominfo dalam mengatur izin siaran dan kepemilikan media di Indonesia. Dapat dikatakan bahwa sumber daya autoritatif yang ada dalam struktur kepemilikan media penyiaran di Indonesia saat ini dimiliki oleh Kemenkominfo.

KPI sendiri pada tahun 2006 telah mengajukan JR ke MK untuk menentang lahirnya rangkaian peraturan pemerintah, termasuk PP-LPS, yang dianggap bertentangan dengan UU Penyiaran. Namun MA memutuskan menolak permohonan KPI karena tidak ada isi PP yang bertentangan dengan UU Penyiaran.

Adapun aspek sumber daya alokatif dalam struktur kepemilikan media 
penyiaran, kita dapat melihatnya pada kanal frekuensi dan belanja iklan. Kedua hal inilah yang menjadi sumber daya yang diperebutkan oleh industri penyiaran.

Dalam hal frekuensi, sistem penyiaran televisi swasta di Indonesia menggunakan gelombang frekuensi radio pada pita Ultra High Frequency (UHF)terrestrial penerimaan tetap tidak berbayar (free to air). Sedangkan sumber daya frekuensi di masing-masing wilayah sifatnya terbatas. Oleh karena itu kanal frekuensi dikelola dan diatur oleh pemerintah. Dalam Keputusan Menteri Perhubungan no.KM 76 tahun 2003 tentang Rencana Induk (Masterplan) Frekuensi Radio Penyelenggaraan Telekomunikasi Khusus untuk Keperluan Televisi Siaran Analog pada Pita Ultra High Frequency (UHF), disebutkan bahwa di sebuah wilayah layanan siaran terutama Ibukota Provinsi jumlah maksimal stasiun televisi adalah 14 kanal. Itupun terdapat 2 kanal yang harus disisakan untuk transisi ke televisi digital. Di beberapa wilayah kabupaten bahkan hanya disediakan 7 kanal frekuensi (pasal 6 ayat (1) \& (2) Keputusan Menteri Perhubungan no.KM 76 tahun 2003).

Data laporan tahunan KPI tahun 2010 memaparkan tentang kanal frekuensi yang telah dipakai oleh 10 LPS Eksisting di tingkat provinsi di Indonesia. Data KPI tersebut berasal dari 10 LPS Eksisting yang telah menerapkan SSJ melalui perubahan stasiun relai menjadi LPS anggota jaringan. Datanya dapat dilihat dibawah ini:

Tabel 1. Jumlah TV Nasional yang Memenuhi Ketentuan SSJ Tahun 2010

\begin{tabular}{lll}
\hline NO & PROVINSI & $\begin{array}{l}\text { JUMLAH TV } \\
\text { NASIONAL }\end{array}$ \\
\hline 1. & Aceh & 4 LPS \\
2. & Sumatera Barat & 8 LPS \\
3. & Sumatera Utara & 10 LPS \\
4. & Sumatera Selatan & 10 LPS \\
5. & Jambi & 6 LPS \\
6. & Bengkulu & 4 LPS \\
7. & Lampung & 9 LPS \\
8. & Riau & 9 LPS \\
9. & Kepulauan Riau & 5 LPS \\
10 & Jawa Tengah & 10 LPS \\
11. & Jawa Barat & 10 LPS
\end{tabular}

\begin{tabular}{lll}
\hline NO & PROVINSI & $\begin{array}{l}\text { JUMLAH TV } \\
\text { NASIONAL }\end{array}$ \\
\hline 12. & Jawa Timur & 10 LPS \\
13. & Banten & 2 LPS \\
14. & D.I. Yogyakarta & 10 LPS \\
15. & Bali & 10 LPS \\
16. & Kalimantan Barat & 9 LPS \\
17. & Kalimantan Selatan & 9 LPS \\
18. & Kalimantan Tengah & 3 LPS \\
19. & Kalimantan Timur & 9 LPS \\
20. & Sulawesi Selatan & 9 LPS \\
21. & Sulawesi Utara & 10 LPS \\
22. & Sulawesi Tenggara & 3 LPS \\
23. & Sulawesi Tengah & 4 LPS \\
24. & Bangka Belitung & 3 LPS \\
25. & Gorontalo & 1 LPS \\
26. & Nusa Tenggara Timur & 4 LPS \\
27. & Nusa Tenggara Barat & 4 LPS \\
28. & Maluku & 4 LPS \\
29. & Papua & 7 LPS \\
\hline
\end{tabular}

Sumber: Laporan Tahunan KPI Tahun 2010, hlm.75

Data KPI di atas tidak menyebutkan 4 provinsi, yaitu DKI Jakarta, Sulawesi Barat, Maluku Utara dan Papua Barat. Untuk provinsi DKI Jakarta sudah jelas bahwa 10 LPS Eksisting sudah ada disana. Adapun tidak dicantumkannya data TV Nasional pada 3 provinsi lainnya menunjukkan bahwa di provinsi-provinsi tersebut tidak terdapat satupun dari anggota jaringan 10 LPS Eksisting.

Data diatas juga menunjukkan bahwa 10 LPS Eksisting telah menguasai kanal frekuensi di provinsi-provinsi tergolong maju seperti Sumatera Utara, Sumatera Selatan, Jawa Tengah, Jawa Barat, Jawa Timur, Yogyakarta, Bali dan Sulawesi Utara. Dapat diartikan bahwa peluang usaha bagi LPS baru di provinsi-provinsi tersebut sudah tertutup, apalagi bagi Lembaga Penyiaran Komunitas (LPK). Peluang yang masih tersedia bagi LPS baru terdapat di provinsiprovinsi yang relatif kurang maju terutama dari segi ekonomi Pendapatan Asli Daerah (PAD).

Sumber daya alokatif lainnya dalam struktur kepemilikan media penyiaran di Indonesia terkait dengan sumber pendapatannya. Bagi televisi FTA, sumber pendapatannya berasal dari iklan 
sebagaimana diatur dalam pasal 19 UU Penyiaran. Data pertumbuhan belanja iklan di Indonesia oleh media televisi menyerap dikuasai oleh 10 LPS Eksisting. hampir rata-rata $60 \%$ dari total belanja iklan di media. Data berikut memperlihatkan pendapatan kotor iklan televisi yang

Tabel 2. Pendapatan Kotor Iklan Televisi

10 LPS Eksisting Periode Januari - April 2012

\begin{tabular}{llcrll}
\hline No & Channels & \multicolumn{2}{l}{ Januari - April 2012 } & Average & $\begin{array}{l}\text { Average By } \\
\text { Group }\end{array}$ \\
\hline 1 & RCTI & $\mathrm{Rp}$ & $2,396,880,462$ & $15.75 \%$ & \\
2 & MNCTV & $\mathrm{Rp}$ & $2,054,468,968$ & $13.50 \%$ & $37 \%$ \\
3 & GLOBALTV & $\mathrm{Rp}$ & $1,179,417,370$ & $7.75 \%$ & \\
4 & SCTV & $\mathrm{Rp}$ & $2,130,560,411$ & $14.00 \%$ & $23,50 \%$ \\
5 & INDOSIAR & $\mathrm{Rp}$ & $1,445,737,422$ & $9.50 \%$ & \\
6 & ANTV & $\mathrm{Rp}$ & $1,255,508,814$ & $8.25 \%$ & $14,50 \%$ \\
7 & TV ONE & $\mathrm{Rp}$ & $951,143,041$ & $6.25 \%$ & \\
8 & TRANS TV & $\mathrm{Rp}$ & $1,635,966,030$ & $10.75 \%$ & $21,75 \%$ \\
9 & TRANS 7 & $\mathrm{Rp}$ & $1,674,011,752$ & $11.00 \%$ & $3,25 \%$ \\
10 & METRO TV & $\mathrm{Rp}$ & $494,594,381$ & $3.25 \%$ & $100 \%$
\end{tabular}

Sumber: The Nielsen Company

Dari paparan di atas dapatterlihat bahwa struktur kepemilikan media penyiaran di Indonesia amat terkait dengan peraturan yang memberikan keistimewaan bagi 10 LPS Eksisting, baik dalam UU Penyiaran maupun PP-LPS serta Peraturan Menkominfo. Hal itu turut dipengaruhi oleh sumber daya alokatif yang mereka miliki, terutama sumber daya modal, sarana \& prasarana, SDM, dan teknologi yang telah dimiliki oleh 10 LPS Eksisting tersebut. Bahkan ketika ke-10 LPS eksisting itu mengkonsolidasikan diri dalam kelompok-kelompok usaha media (media group), kekuatan mereka bertambah besar dan menjadi sumber daya autoritatif dalam struktur kepemilikan media penyiaran di Indonesia, terutama saat mereka mendominasi penguasaan kanal frekuensi dan belanja iklan yang menjadi sumber daya alokatif juga.

Pada masa sebelum UU Penyiaran 2002, media televisi swasta di Indonesia dapat bersiaran secara nasional dan yang salurannya dapat ditangkap melalui antena Ultra High Frequency (UHF) atau Very High Frequency (VHF) (terrestrial) dengan model penerimaan tetap tak berbayar (free to air). Sejak RCTI bersiaran pada tahun 1989 sebagai stasiun televisi swasta pertama, hingga saat ini terdapat 10 stasiun televisi swasta yang bersiaran nasional di Indonesia, yaitu RCTI (1989), SCTV (1989), MNC TV(sebelumnya bernama TPI) (1990), ANTV (1993), Indosiar (1995), Metro TV (2000), Trans TV (2001), Global TV (2001), TVOne (sebelumnya bernama Lativi) (2001) dan Trans 7 (sebelumnya bernama TV7) (2001). Semua stasiun televisi diatas berlokasi di Provinsi DKI Jakarta. Stasiun-stasiun televisi tersebut dapat bersiaran secara nasional dengan menggunakan stasiun pemancar (relai) di berbagai daerah yang dapat memancarkan siaran dari Jakarta.

Dalam proses persaingan bisnis diantara sepuluh stasiun televisi nasional itu kemudian menyebabkan terjadinya penggabungan beberapa televisi dalam satu perusahaan induk (holding company) yang disebut kelompok usaha media (media group). Hingga tahun 2011 dengan bergabungnya SCTV-Indosiar dalam perusahaan induk EMTEK, terdapat 5 kelompok usaha dari 10 LPS Eksisting yaitu MNC Group, EMTEK Group, Trans Corp, 
Viva Group dan Media Group. Hanya Media Group yang memiliki satu LPS Televisi yaitu Metro TV. Bahkan kelompok-kelompok usaha media tersebut juga melebarkan jaringan bisnisnya pada LPS lokal maupun Lembaga Penyiaran Berlangganan (LPB).

Tabel 3. Daftar Kelompok Usaha Media (Media Group) 10 LPS Televisi Eksisting dan Market Share Tahun 2011

\begin{tabular}{|c|c|c|c|c|c|c|}
\hline No. & Grup Media & Pemilik & Stasiun Televisi & $\begin{array}{l}\text { Tahun } \\
\text { Siaran }\end{array}$ & Mar & $\begin{array}{l}\text { et Share } \\
\%)\end{array}$ \\
\hline \multirow{3}{*}{1.} & \multirow{3}{*}{$\begin{array}{l}\text { MNC Group } \\
\text { Mediacomm) }\end{array}$} & \multirow{3}{*}{$\begin{array}{l}\text { Hari Tanoe- } \\
\text { soedibjo }\end{array}$} & \multirow{3}{*}{$\begin{array}{l}\text { RCTI } \\
\text { Global TV } \\
\text { MNCTV (sebelumnya } \\
\text { TPI) }\end{array}$} & 1989 & 19 & \multirow{3}{*}{36,7} \\
\hline & & & & 2001 & 5,1 & \\
\hline & & & & 1990 & 12,6 & \\
\hline \multirow{2}{*}{2.} & \multirow{2}{*}{$\begin{array}{l}\text { Elang Mahkota Teknolo- } \\
\text { gi (EMTEK) Group }\end{array}$} & Eddy Kusnadi & SCTV & 1989 & 17,3 & \multirow{2}{*}{31,5} \\
\hline & & Sariaatmadja & Indosiar & 1995 & 14,2 & \\
\hline \multirow[b]{2}{*}{3.} & \multirow[b]{2}{*}{ Trans Corp (CT Corp) } & Chairul & Trans TV & 2001 & 12,1 & \multirow[b]{2}{*}{18,5} \\
\hline & & Tanjung & $\begin{array}{l}\text { Trans } 7 \\
\text { (sebelumnya TV 7) }\end{array}$ & 2001 & 6,4 & \\
\hline \multirow[b]{2}{*}{4.} & \multirow[b]{2}{*}{$\begin{array}{l}\text { Viva Group (Bakrie \& } \\
\text { Brothers) }\end{array}$} & \multirow[b]{2}{*}{$\begin{array}{l}\text { Anindya } \\
\text { Bakrie }\end{array}$} & ANTV & 1993 & 4,2 & \multirow[b]{2}{*}{8,7} \\
\hline & & & $\begin{array}{l}\text { TV One } \\
\text { (sebelumnya Lativi) }\end{array}$ & 2001 & 4,5 & \\
\hline 5. & Media Group & Surya Paloh & Metro TV & 2000 & 1,9 & 1,9 \\
\hline
\end{tabular}

Sumber: Diolah dari data riset Merlyna Lim, @crossroads: Democratization and Corporatization of Media in Indonesia, Participatory Media Lab at Arizona State University \& Ford Foundation, 2011, hlm. 12

Kemapanan ekonomi dan sumber daya yang besar yang telah dimiliki oleh 5 kelompok usaha media itulah yang turut mempengaruhi pola pikir sebagian kelompok masyarakat untuk memahami pengistimewaan tersebut. Seperti yang diungkapkan oleh informan Hayono Isman bahwa hampir seluruh anggota komisi I DPR RI sepakat untuk tidak membuat industri yang sudah besar itu menjadi kecil. Sebagaimana yang disampaikan oleh anggota Komisi 1 DPR RI Hayono Isman:

"Tapi intinya semua sepakat harus ada diversity of ownership. Kita di komisi 1 ada satu ungkapan "yang besar jangan dipenggal kepalanya, yang kecil jangan dihalangi jadi besar". Atau dengan kata lain "Yang besar jangan dikecilkan, yang kecil jangan dihalangi untuk menjadi besar". Begitu lah. Karena bagaimanapun juga industri yang ada sekarang ini memberikan manfaat yang besar kepada rakyat, dalam bentuk hiburan."

\section{Dinamika Interaksi Agen dan Struktur Pe- nyiaran}

Dinamika interaksi agen dan struktur dalam mencegah konsentrasi kepemilikan media televisi swasta di Indonesia sebenarnya sudah terlihat dalam proses aksi akuisisi IDKM oleh EMTEK. Seperti telah dijelaskan di atas, wacana akuisisi IDKM oleh EMTEK ini sebenarnya telah muncul sejak tahun 2006. Artinya hampir 4 tahun lamanya EMTEK harus menahan diri untuk tidak langsung melakukan akuisisi terhadap IDKM. Hal itu tentu saja dipengaruhi oleh aturan perundang-undangan terutama UU Penyiaran dan keberadaan lembaga KPlyang hadir sebagai regulator bidang penyiaran. Apalagi saat pihak EMTEK melaporkan rencana aksi tersebut kepada KPI tahun 2008-2009, KPI saat itu telah memposisikan sebagai pihak yang menentang aksi akuisisi itu dengan memberi peringatan akan potensi pelanggaran UU Penyiaran. Kegamangan itulah yang membuat EMTEK harus berpikir panjang untuk mengakuisisi IDKM. Dalam hal ini EMTEK sebagai agen turut dipengaruhi oleh struktur penyiaran Indonesia yang diciptakan oleh UU Penyiaran tahun 2002.

Dinamika agen dan struktur yang kedua 
dapat dilihat pada langkah yang diambil oleh KPI dalam menyikapi aksi akuisisi IDKM oleh EMTEK. Seperti yang disampaikan oleh informan M. Riyanto bahwa langkah KPI mengeluarkan pendapat hukum (legal opinion) dalam kasus akuisisi IDKM oleh EMTEK ini disebabkan karena keterbatasan wewenang dan posisi hukum (legal standing) KPI pasca keputusan MK tahun 2004. Keputusan MK itu mereduksi peran KPI hanya mengurus isi siaran, sementara urusan izin siaran menjadi wewenang Kemenkominfo.

Keterbatasan kewenangan itulah menjadi hambatan yang utama bagi KPI dalam mengawal kasus ini. Sebagaimana disampaikan oleh informan M. Riyanto:

"Hambatannya yang jelas dalam keterbatasan kewenangan didasarkan pada kewajiban regulasi. Itu hambatan yang paling utama. Kalau itu tidak direduksi dengan PP yang diambil kewenangan pemerintah, saya pikir KPI bisa melakukan sesuatu yang lebih untuk mengawal ini. Maksudnya untuk menjaga agar tidak terjadi monopoli. Tapi karena sudah diambil dengan ketentuan peraturan pemerintah, kewenangan ada disana, kita tidak bisa berbuat banyak."

Dapat dikatakan bahwa struktur penyiaran yang saat ini berlaku, telah membatasi gerak KPI dalam bertindak lebih tegas dalam aksi akuisisi IDKM oleh EMTEK maupunmengatursistem kepemilikan media penyiaran di Indonesia. Namun KPI masih melihat celah dalam putusan MK tersebut tidak mereduksi tugas dan kewajiban KPI dalam UU Penyiaran untuk ikut membangun iklim persaingan yang sehat antara lembaga penyiaran dan industri terkait sesuai pasal 8 ayat (3) UU Penyiaran. Celah itulah yang digunakan oleh KPI sebagai dasar untuk bertindak dan mengambil sikap untuk kasus kepemilikan media yang sebenarnya sudah bukan menjadi ranah KPI lagi.

Ketidakberpihakan Kemenkominfo kepada publik dengan membiarkan kondisi pemusatan kepemilikan media membuat masyarakat penyiaran menaruh harapan yang besar kepada KPI untuk membenahi sistem kepemilikan media penyiaran di Indonesia. Hal itu tercermin dari keinginan publik termasuk KIDP, agar peran KPI dapat diperluas dan diperkuat. Sebagaimana yang disampaikan oleh informan Umar Idris:

"KIDP memang menginginkan wewenang KPI diperluas, diperkuat. Bukan hanya memberi referensi atas perizinan. Kita ingin KPI menjadi lembaga pemberi izin dan pemberi sanksi pula. Makanya mereka senang dan ya memang seperti ini sebetulnya governance yang mau kita bangun."

Soal penguatan KPI ini pula yang menjadi salah satu isu dalam pembahasan revisi UU Penyiaran. Menurut informan Wakil Ketua Komisi I DPR RI Hayono Isman, Komisi I dalam posisi mencermati perbedaan pemikiran yang berkembang dalam diskusi tujuh orang pakar yang diminta oleh DPR RI. Ketujuh pakar tersebut adalah Sasa Djuarsa Sendjaja, Ade Armando, Parni Hadi, Amir Effendi Siregar, Ishadi SK, Soekarno Abdulrachman dan Paulus Widianto. Sebagaimana disampaikan oleh informan Hayono Isman:

"Tokoh-tokoh itupun terbagi didalam dua atau tiga pemikiran. Ada perbedaan di (soal) kepemilikan, SSJ, dan di penguatan KPI, kemudian pemisahan LPP dari UU penyiaran dengan UU tersendiri. Ini yang akan menjadi sesuatu yang menarik. Komisi I sepakat kita tidak mungkin menghalangi terjadinya perbedaan pemikiran. Nanti tinggal komisi I memberikan keputusan politiknya mana yang tepat bagi kepentingan rakyat Indonesia."

Dalam pandangan KIDP, upaya untuk merubah struktur kepemilikan media penyiaran di Indonesia hanya dapat dilakukan melalui dua cara, yaitu perubahan UU Penyiaran di DPR dan tafsir konstitusional MK yang putusannya bersifat final. Sebagaimana yang diutarakan oleh informan Umar Idris:

"Kita ingin ada penataan penyiaran 
yang itu diawali dengan tafsir yang tunggal, tafsir yang konstitusional dari MK. Kita ingin ada tafsir yang jadi pegangan semua pihak. Kita minta penyalahgunaan pasal tersebut berakhir. Sehingga kita berpegang pada tafsir konstitusional yang baru dari MK. Itu harapan kita dari JR."

Dalam hal ini KIDP melihat ada peluang yang terdapat dalam struktur hukum tatanegara di Indonesia yang menempatkan MK sebagai lembaga negara yang memiliki kekuasaan untuk memberikan penafsiran tunggal terhadap perbedaan penafsiran atas undang-undang. MK merupakan lembaga kekuasaan kehakiman yang lahir setelah perubahan UUD 1945 yang bertujuan untuk menegakkan konstitusi dan prinsip negara hukum yang menempatkan UUD 1945 sebagai hukum tertinggi. Salah satu wewenang MK adalah pengujian undang-undang terhadap UUD 1945.

Putusan MK yang bersifat final dianggap dapat menjadi kekuatan untuk merubah struktur kepemilikan media yang ada di Indonesia. Hal itu diatur dalam pasal 10 ayat (1) UU no.24 tahun 2003 tentang Mahkamah Konstitusi yang menyatakan bahwa Mahkamah Konstitusi berwenang mengadili pada tingkat pertama dan terakhir yang putusannya bersifat final. Bagi KIDP jika MK mengabulkan gugatan mereka, hal itu akan mempengaruhi struktur dalam sistem kepemilikan media penyiaran di Indonesia.

Dari paparan data di atas, terlihat bahwa struktur kepemilikan media televisi swasta pasca munculnya UU Penyiaran no.32 tahun 2002, tidak berubah dari kondisi pada awal reformasi, dimana kepemilikan media televisi swasta dikuasai oleh pengusaha yang berorientasi pada bisnis dan keuntungan (profit oriented). Semangat kebebasan (liberalisasi)yang digaungkan oleh reformasi 1998 membawa kekuasaan modal ke dalam setiap sistem sosial di Indonesia, termasuk sistem kepemilikan media televisi swasta. Sistem kapitalisme inilah yang mendominasi struktur kepemilikan media televisi swasta di Indonesia hingga saat ini.

Maka, aksi korporasi PT Elang Mahkota
Teknologi Tbk (EMTEK) terhadap PT Indosiar Karya Media (IDKM) yang berimplikasi pada penggabungan media televisi Indosiar dan SCTV dalam satu grup media, merupakan konsekuensi yang tidak dapat dihindarkan dari sistem kapitalisme global. Sebagaimana yang dinyatakan oleh Golding dan Murdock bahwa dalam perubahan institusi media, seluruh media memiliki siklus yang sama. Awalnya media berproduksi dalam skala kecil dan bersifat personal. Pada masa ini pola distribusi dan penjualan terpisah. Saat teknologi bertambah maju, pola produksi berubah menjadi industrialisasi dan pola konsumsi bertambah besar dan impersonal. Proses diferensiasi ini digantikan oleh suatu periode dimana pertumbuhan industri mengalami kejenuhan, peningkatan biaya, penurunan pendapatan dan perubahan pola permintaan. Dari diferensiasi inilah proses konsentrasi dimulai (Golding \& Murdock, 1997:5).

Kompetisi yang terjadi terutama dalam 10 LPS Eksisting yang lahir sebelum UU Penyiaran 2002 pada kenyataannya memunculkan grup-grup media televisi. Bahkan grup media tersebut juga menguasai jenis media lainnya seperti cetak, radio dan online. Maka, untuk dapat bisa bersaing dengan grup media yang ada, praktik penggabungan usaha menjadi hal yang tak terelakkan bagi perusahaan media yang ingin tetap bertahan hidup.

Gejala ini oleh Mosco disebut tahap Spasialisasi. Bagi industri, seperti industri media penyiaran, spasialiasi ini membawa pengaruh pada perubahan pola produksi, distribusi, pemasaran hingga jaringan pelanggan yang tidak lagi memiliki batasan wilayah. Ekonomi politik komunikasi secara khusus mendefinisikan spasialisasi pada proses perluasan bisnis perusahaan media dalam industri komunikasi. Proses-proses konsentrasi, integrasi, baik vertikal maupun horizontal, kerjasama strategis, merger dan akuisisi menjadi perhatian penting dalam proses spasialisasi ini.

Praktik aksi korporasi IDKM oleh EMTEK juga mencerminkan upaya pemusatan/ konsentrasi kepemilikan media yang 
mengarah pada konglomerasi media. Sebagaimana dinyatakan oleh Sudibyo bahwa integrasi ekonomi yang terjadi melalui merger dan akuisisi membuka jalan bagi berkembangnya fenomena konglomerasi (Sudibyo, 2004:7). Dapat dikatakan bahwa aksi korporasi tersebut murni berlatar belakang bisnis dimana EMTEK mengakuisisi IDKM bertujuan untuk memperkuat bisnis media sehingga dapat bersaing dengan grup media yang lain.

Faktor efisiensi dan efektifitas merupakan landasan terjadinya aksi akuisisi tersebut, yakni menekan pengeluaran dan meningkatkan keuntungan. Melalui penggabungan usaha, suatu perusahaan media akan menjadi kuat karena bertambahnya modal, teknologi dan fasilitas yang didapat dari bersatunya dua perusahaan. Namun, penggabungan tersebut juga akan berdampak pada efisiensi tenaga yakni perampingan struktur organisasi serta pengurangan jumlah tenaga karyawan.

Kekuatan kapitalisme dalam struktur kepemilikan media televisi swasta di Indonesia turut didukung oleh lemahnya regulasi di bidang penyiaran. Hal itu terbukti dari tidak mampunya UU Penyiaran no.32/2002 mencegah terjadinya aksi korporasi IDKM oleh EMTEK. Praktik jualbeli saham pada level perusahaan induk (holding company) pemilik perusahaan media penyiaran, tidak dapat dijangkau oleh pasal-pasal yang ada dalam UU Penyiaran. Pasal 18 ayat (1) UU Penyiaran yang mengatur pembatasan pemusatan kepemilikan media tidak secara tegas melarang praktik konsentrasi tersebut. Frasa "dibatasi" dalam pasal 18 ayat (1) kemudian dapat ditafsirkan bukan sebagai pelarangan bagi industri untuk melakukan aksi penggabungan usaha. Begitu pula dengan pasal 34 ayat (4) yang mengatur tentang larangan pemindahtanganan izin penyiaran, juga dapat ditafsirkan hanya berlaku pada perusahaan media pemilik izin penyiaran. Argumentasi itulah yang digunakan oleh pihak EMTEK bahwa izin penyiaran tetap berada pada PT Indosiar Visual Mandiri
(IVM), anak perusahaan IDKM. Lemahnya regulasi inilah yang menjadi celah bagi perusahaan media untuk melakukan praktik penggabungan usaha dengan cara menguasai saham perusahaan induk.

\section{Simpulan}

Sejak reformasi 1998, struktur yang terdapatdalam ranah penyiaran di Indonesia, termasuk sistem kepemilikan media, lebih mencerminkan kekuasaan modal (kapitalisme) yang terus berupaya meningkatkan keuntungan setinggi-tingginya melalui penguasaan beberapa stasiun televisi dan juga media lain (cross ownership). Aksi akuisisi IDKM oleh EMTEK pada tahun 2011 merupakan suatu bentuk pencaplokan perusahaan yang lemah (IDKM) yang dilakukan oleh perusahaan yang kuat (EMTEK) dengan harapan mendapatkan keuntungan dari integrasi produksi dan distribusi. Hal ini membuktikan bahwa struktur kapitalisme lah, dalam bentuk persaingan usaha berlandaskan hukum pasar, yang mendorong terjadinya aksi korporasi tersebut agar kedua perusahaan dapat bertahan hidup di dalam persaingan bisnis media penyiaran di Indonesia.

Meski aksi akuisisi IDKM oleh EMTEK tidak dapat dikategorikan sebagai tindakan monopoli, namun aksi korporasi tersebut mencerminkan kondisi pemusatan (konsentrasi) kepemilikan media penyiaran di Indonesia, dimana satu perusahaan dapat menguasai saham beberapa perusahaan media, meski hal itu terjadi pada level perusahaan induk (holding company). Konsentrasi kepemilikan media penyiaran di Indonesia dapat dilihat pada penguasaan 10 LPS Eksisting bersiaran nasional yang bergabung ke dalam 5 kelompok usaha media (media group) besar yang menguasai jangkauan siaran dan juga pendapatan iklan. Hal ini juga dapat dikatakan bahwa struktur kepemilikan media televisi swasta di Indonesia merupakan bentuk oligopoli.

Terbentuknya struktur kepemilikan ini disebabkan karena peraturan perundangundangan baik UU Penyiaran maupun 
Peraturan Pemerintah yang mengatur televisi swasta (PP-LPS) memberikan peluang dan pengistimewaan terhadap 10 LPS Eksisting. Hal itu turut dipengaruhi oleh sumber daya alokatif yang telah dimiliki oleh LPS Eksisting mencakup sumber daya kanal frekuensi, sumber daya modal, SDM, infrastruktur dan teknologi, serta sumber daya autoritatif dimana terjadi pergeseran wewenang dalam mengatur izin siaran dari KPI kepada Kemenkominfo. Semangat kebangsaan (nasionalisme) terutama dalam rangka menumbuhkan industri penyiaran televisi nasional juga berkontribusi pada pembentukan struktur kepemilikan media penyiaran yang terkonsentrasi tersebut. Hal ini pula yang menimbulkan kesepakatan pemikiran di komisi I DPR RI dengan istilah "Yang besar jangan dikecilkan, yang kecil jangan dihambat untuk menjadi besar."

UU Penyiaran pada dasarnya memiliki semangat melarang konsentrasi kepemilikan apalagi monopoli kepemilikan media penyiaran. Namun celah-celah dalam peraturan yang ragu seperti frase "dibatasi" dan "badan hukum" dalam pasal 18 ayat (1) dan "pihak lain" dalam pasal 34 ayat (4) memberikan peluang bagi kalangan industri televisi besar untuk menguasai beberapa stasiun televisi dengan cara membeli saham pada level perusahaan induk. Padahal jika dilihat dari laporan keuangan yang terkonsolidasi, perusahaan induk media memiliki sifat pengendali anak perusahaan media. Artinya, perubahan saham di perusahaan induk akan menyebabkan perubahan manajemen dan kebijakan operasional anak perusahaan media.

Celah dalam regulasi itulah yang menjadi strategi bisnis industri media di Indonesia untuk menguasai lebih dari satu stasiun televisi, yaitu dengan cara menguasai saham perusahaan induk (holding company) yang memiliki perusahaan media televisi. Hal ini terjadi dalam aksi akuisisi PT Elang Mahkota Teknologi Tbk (EMTEK) terhadap PT Indosiar Karya Media Tbk (IDKM) yang merupakan perusahaan induk dari PT Indosiar Visual Mandiri (Indosiar). Strategi ini digunakan untuk mensiasati aturan tentang kepemilikan dan pelarangan pemindahan izin penyiaran sesuai pasal 18 ayat (1) dan pasal 34 ayat (4) UU Penyiaran yang tidak secara jelas memberi batasan soal kepemilikan apakah hanya pada level perusahaan pemilik IPP atau juga pada level perusahaan induk.

Komisi Penyiaran Indonesia (KPI) dan Koalisi Independen untuk Demokratisasi Penyiaran (KIDP) merupakan agensi-agensi sosial yang berperan besar dan signifikan dalam membuat kasus akuisisi IDKM oleh EMTEK berkembang lebih besar pada isu tentang sistem kepemilikan media penyiaran di Indonesia. Melalui gugatan warga negara (citizen lawsuit), dilanjutkan dengan pendapat hukum (legal opinion) KPI dan kemudian ditindaklanjuti oleh uji materi (judicial review) yang dilakukan KIDP ke MK, dipastikan akan merubah struktur kepemilikan media penyiaran di Indonesia ke depan, meskipun struktur kepemilikan media yang digambarkan diatas akan mempengaruhi kebijakan MK dan pada akhirnya tidak akan memenuhi ekspektasi para pemohon.

KPI sendiri, meski telah diposisikan hanya mengatur isi siaran, namun dalam peristiwa aksi akuisisi IDKM oleh EMTEK dan proses persidangan di MK, berupaya untuk memperkuat kewenangannya kembali untuk mengatur izin penyiaran industri media melalui sikap politiknya dalam pendapat hukum (legal opinion) yang menentang aksi akuisisi IDKM oleh EMTEK.

Atas dasar itu, penulis berpendapat bahwa agensi-agensi sosial di bidang penyiaran, terutama mereka yang memperjuangkan keseimbangan antara kekuatan negara, pasar dan kepentingan publik, memiliki kekuatan yang cukup besar untuk mempengaruhi struktur penyiaran yang ada. Bukan tidak mungkin jika kemudian langkah dan gerakan para agensi ini diarahkan pada revisi UU Penyiaran yang sedang dibahas di DPR, akan memiliki kekuatan besar untuk menata sistem penyiaran Indonesia menjadi lebih baik. Termasuk di dalamnya adalah mengenai penguatan peran dan wewenang KPI 
sebagai badan regulasi independen, wakil dari publik.

Mencermati dinamika interaksi di atas, penulis menyarankan dalam rangka membatasi pemusatan kepemilikan media terutama bagi 10 LPS Eksisting agar semua kelompok usaha media (media group) menyatakan secara terbuka bahwa stasiun-stasiun televisi yang ada di dalam kelompoknya merupakan milik satu badan hukum yang sama. Artinya EMTEK mengakui bahwa semua stasiun anggota jaringan SCTV maupun Indosiar adalah satu kepemilikan. Begitu juga dengan kelompok MNC Group, Trans Corp, dan Viva Group.

Selain itu, kelompok usaha media agar menghapus atau menutup stasiun anggota jaringan yang berada di wilayah yang sama. Misalnya jika EMTEK memiliki stasiun SCTV dan Indosiar di DKI Jakarta, maka salah satu stasiun tersebut harus dihapuskan. Hal ini guna memenuhi ketentuan pasal 20 UU Penyiaran yang menyatakan bahwa satu badan hukum hanya boleh bersiaran di satu wilayah siaran.

Pembatasan kepemilikan media yang digunakan di Indonesia adalah melalui pembatasan jangkauan siaran paling banyak $75 \%$ dari seluruh provinsi yang ada. Dengan demikian, pembatasan dari segi stasiun televisi tidak diberlakukan lagi. Artinya suatu badan hukum, terutama perusahaan induk, boleh menguasai sebanyak-banyaknya LPS selama tidak menguasai dua stasiun televisi di satu wilayah yang sama dan tidak lebih dari 24 provinsi.

Terakhir, penulis menyarankan agar KPI dan Kemenkominfo bersama-sama membuat cetak biru (blue print) peluang usaha media televisi di Indonesia yang menggambarkan tatanan jenis dan ragam stasiun televisi yang hendak dikembangkan, agar menjadi pedoman bagi para investor yang tertarik untuk berusaha di bisnis pertelevisian.

\section{DAFTAR REFERENSI}

\section{Buku}

Albarran, Alan. (2002). Management of Electronic Media, Belmont: Wadsworth Thomson Learning

Armando, Ade. (2011). Televisi Jakarta Diatas Indonesia, Yogyakarta:Bentang

Bryman, Alan. (2008). Social Research Methods. $3^{\text {rd }}$ Edition. New York: Oxford University Press

Einstein, Mara. (2004). Media Diversity: Economics, Ownership and the FCC, Mahwah New Jersey: Lawrence Erlbaum Associates

Giddens, Anthony. (1984). The Constitution of Society, Cambridge: Polity Press,

Giddens, Anthony. (1993). New Rules of Sociological Methods. $2^{\text {nd }}$ edition, Cambridge: Polity Press

Golding, Peter dan Graham Murdock (eds). (1997). The Political Economy of the Media, Volume 1, Edward Edgar Publishing Limited

Littlejohn, Stephen W. (2002). Theories of Human Communication $7^{\text {th }}$ Edition, Thomson Learning

McManus, John H. (1994). Market-Driven Journalism: Let the Citizen Beware, Thousand Oaks, CA: Sage

McQuail, Denis. (2000). Mass Communication Theory, $4^{\text {th }}$ Edition, London: Sage Publications 
Ltd.

Mosco, Vincent. (2009). The Political Economy of Communication, $2^{\text {nd }}$ edition, London: Sage Publication Ltd

Neuman, W. Lawrence. (2000). Social Research Methods, Qualitative and Quantitative Approaches, $4^{\text {th }}$ Edition, USA: Allyn and Bacon

Patton, Michael Quinn. (2002). Qualitative Research \& Evaluation Methods, $3^{\text {rd }}$ Edition, USA: Thousand Oaks Sage Publication

Ritzer, George dan Douglas J. Goodman. (2004). Teori Sosiologi Modern (terjemahan) Edisi Keenam, Jakarta: Kencana

Siregar, Amir Effendi. (2012). Menegakkan Demokratisasi Penyiaran: Mencegah Konsentrasi, Membangun Keanekaragaman, Jakarta: Komunitas Pejaten

Straubhaar, Joseph dan Robert LaRose. (2008). Media Now, Understanding Media, Culture, And Technology, Fifth Edition, USA: Thomson Wadsworth

Sudibyo, Agus, dkk. (2004). Ekonomi Politik Media Penyiaran, Jakarta: ISAI \& Yogyakarta: LKiS

Yin, Robert K. (2003). Case Study Research: Design and Methods, Third Edition, USA: Thousand Oaks Sage Publication

\section{Artikel}

Enders, Claire dan Chris Goodall. (2011). Media Ownership Rules, http://www.ahrc.ac.uk/ About/Policy/Documents/EnderspapermediaownershiprulesDec2011.pdf

Lim, Merlyna. (2011). @crossroads: Democratization and Corporatization of Media in Indonesia, Participatory Media Lab at Arizona State University \& Ford Foundation

Nugroho, Yanuar, Dinita Andriani Putri, dan Shita Laksmi. (2012). Mapping The Landscape Of The Media Industry In Contemporary Indonesia, kerjasama Centre for Innovation Policy and Governance (CIPG) and HIVOS Regional Office Southeast Asia, Jakarta

\section{Dokumen}

Keputusan Menteri Perhubungan no.KM 76 tahun 2003

Laporan Tahunan Aliansi Jurnalis Independen (AJI) Tahun 2010

Laporan Tahunan Komisi Penyiaran Indonesia (KPI) tahun 2010

Laporan Tahunan PT Elang Mahkota Teknologi Tbk Tahun 2010

Laporan Tahunan PT Indosiar Karya Media Tbk Tahun 2010

Pandangan Hukum Komisi Penyiaran Indonesia (Pusat) atas Rencana Aksi Korporasi Pengambilahan Saham PT Indosiar Karya Media, Tbk oleh PT Elang Mahkota Teknologi, Tbk.

Pendapat KPPU Nomor A11911 Tentang Pengambilan Saham Perusahaan PT Indosiar Karya Media Tbk oleh PT Elang Mahkota Teknologi Tbk

Peraturan Pemerintah no.50 Tahun 2005 tentang Penyelenggaraan Penyiaran Lembaga Penyiaran Swasta

Risalah Sidang Mahkamah Konstitusi, Perkara nomor 78/PUU-IX/2011, Acara mendengarkan 
keterangan pemerintah, DPR dan pihak terkait, 10 Januari 2012

Risalah Sidang Mahkamah Konstitusi, Perkara nomor 78/PUU-IX/2011, Acara mendengarkan keterangan pihak terkait, 19 Januari 2012

Risalah Sidang Mahkamah Konstitusi, Perkara nomor 78/PUU-IX/2011, Acara mendengarkan keterangan pihak terkait, 2 Februari 2012

Risalah Sidang Mahkamah Konstitusi, Perkara nomor 78/PUU-IX/2011, Acara mendengarkan keterangan pihak terkait dan ahli/saksi, 15 Februari 2012

Risalah Sidang Mahkamah Konstitusi, Perkara nomor 78/PUU-IX/2011, Acara mendengarkan keterangan ahli dan saksi, 23 Februari 2012

Risalah Sidang Mahkamah Konstitusi, Perkara nomor 78/PUU-IX/2011, Acara mendengarkan keterangan ahli dan saksi, 13 Maret 2012

Risalah Sidang Mahkamah Konstitusi, Perkara nomor 78/PUU-IX/2011, Acara mendengarkan keterangan ahli dan saksi, 5 April 2012

Undang-Undang no 8 Tahun 2011 tentang perubahan atas Undang-Undang no.24 Tahun 2003 tentang Mahkamah Konsitusi

Undang-Undang no.32 Tahun 2002 Tentang Penyiaran

Undang-Undang no.5 Tahun 1999 tentang Larangan Praktek Monopoli dan Persaingan Usaha Tidak Sehat

\section{Berita}

Majalah Tempo Edisi. 39/XXXV/20 - 26 November 2006

www.detik.com

www.hukumonline.com

www.investor.co.id

www.kontan.co.id

www.mediaindonesia.com

www.okezone.com

www.presidensby.info

www.republika.co.id 